

\title{
THE ANTIMICROBIAL ACTIVITY OF COMBINATIONS WITH OLIVE OIL (Olea europaea L.) OF FATTY ACIDS OF SOME MEDICINAL PLANTS AGAINST SOME PATHOGENS
}

\author{
Elif Ayşe Erdoğan Eliuz* \\ Address(es): Assist. Prof. Elif Ayșe Erdoğan Eliuz \\ Department of Food Technology, Vocational School of Technical Sciences, Mersin University, Mersin, Turkey.
}

*Corresponding author: eliferdogan81@gmail.com

doi: 10.15414/jmbfs.2020.9.5.941-945

\section{ARTICLE INFO}

Received 22. 4. 2019

Revised 25. 10. 2019

Accepted 11. 11. 2019

Published 1. 4. 2020

Regular article

OPEN $\partial_{\text {Access }}$

\begin{abstract}
In this study, the combinations with Olea europaea (olive) oil of fatty acids of Punica granatum, Calendula officinalis and Helianthus annuus seeds to detect interactions on Escherichia coli, Enterococcus faecalis, Staphylococcus aureus, Bacillus subtilis, Candida albicans and Candida parapsilosis were determined by antimicrobial checkerboard method. It was revealed that linoleic, oleic, palmitic and stearic acid were to be main component of O. europaea, C. officinalis and H. Annuus. By contrast, P. granatum seed oil contained more than $70 \%$ conjugated linolenic acids (CLnA), followed by linoleic acid, oleic acid, stearic and palmitic by using GC-FID. Exposed microorganisms to combinations with $O$. europaea oil of fatty acids of $P$. granatum, $C$. officinalis, $H$. annuus overnight, according to FICI (Fractional Inhibitory Concentration Index) interpretation model, remarkable IndE was observed as $71.43 \%$ against E.coli and $76.19 \%$ against S. aureus, B.subtilis, C.albicans while lower AntE noted as $28.57 \%$ against E.coli and $23.81 \%$ against S.aureus, B.subtilis, C.albicans.
\end{abstract}

\section{INTRODUCTION}

Plant-derived antimicrobials like secondary metabolites are very important sources of novel therapeutics and used in traditional medicine for years. The well-known examples of those are terpenes, phenols and fatty acids. In spite of the fact that seconder metabolites are high antimicrobial potents, their interactions with each other may decrease or increase this effect. Several studies have reported that various components of plant oils interact with antibiotics to changes antimicrobial performance and may lead to new approaches for treating infectious diseases (Delaquis et al., 2002; Hemaiswarya et al., 2008; Hammer et al., 2012; Kon and Rai, 2012; Lv et al., 2011). However, there are not any studies with the interaction of the olive oil with the other oils from medicinal plants such as safflower, sunflower and pomegranate.

Olive (Olea europaea), sunflower (Helianthus annuиs L.), safflower Calendula officinalis and pomegranate (Punica granatum) are important medicinal plants used in food, cosmetic and pharmacology areas (Flagella et al., 2002; Ashwlayan et al., 2018; Pardo et al., 2011; Meerst et al., 2009). Olive (Olea europaea), known as "Mediterranean diet", is the most important traditional food because of its beneficial functions on human health, preventive effects on some cardiovascular and cancer diseases. It has a rich biochemical content and includes terpenic alcohols, sterols, hydrocarbon derivatives, fatty acids, essential oils and antioxidants (Artajo et al., 2006; Tuck and Hayball, 2002). Olive oil has different ratios of fatty acid ratios such as oleic (C18: 1), palmitic (C16: 0), linoleic (C18: 2), palmitoleic (C16: 1), stearic (C18: 0), linolenic (C18: 3) and the main component is always oleic acid. These compounds have antimicrobial properties on many pathogenic microorganisms such as Escherichia coli, Klebsiella pneumoniae and Bacillus cereus (Aziz et al., 1998, Trichopoulou et al., 2003). $P$. granatum is an important medicinal plant used to treat various diseases such as cardiovascular diseases, cancer, aphthae, diarrhea, diabetes, infantile brain ischemia, gastritis, alzheimer and ulcer due to its secondary metabolites in pharmaceutical industry (Yılmaz and Usta, 2010; Jurenka, 2008). Pomegranate, which is seen in Mediterranean shrub formation, is frequently consumed in our country and pomegranate seeds is constitute the waste of this plant. Pomegranate oil extracted from its seeds contain important fatty acids such as linoleic, oleic, palmitic acid, punic acid. Especially, the seeds, which contain a high proportion of conjugated linolenic acid (CLnA) isomers, make the fruit more valuable (Firestone, 2005). Calendula officinalis, is a member of the family Asteraceae, grown especially in parks and gardens due to its attractive appearance. It was reported that the fatty acids extracted from its seed has bioactive components such as triterpene saponosites, triterpene esters, phenolic compounds, carotenoids and volatile components. (Özgül-Yücel 2005; Gruenwald et al., 2000). In addition, sunflower (Helianthus annuus L.) is one of the most important oil plants produced in the world and Turkey. It grows in almost every region of our country (Turkey) and meets $50 \%$ of vegetable oil consumption. The oil obtained from the seeds regulates metabolism and has vital benefits in the reproductive and digestive system. But, it has been associated with obesity in recent years. Sunflower oil contains high amounts of unsaturated fatty acids $(82.75 \%)$ and were reported to constitute of mostly oleic acid, linoleic, linolenic acid (Kirbaşlar et al., 2012).

The objective of this study was to assess the susceptibility of some pathogen microorganisms to single and combinations with $O$. europaea oil of fatty acids of $P$. granatum, $C$. officinalis, $H$. annuus to detect synergistic effect (SynE) or indifferent effect (IndE) or antagonistic effect (AntE), using checkerboard method.

\section{MATERIAL AND METHODS}

\section{Plant Materials and Chemical Analysis}

Seeds of $P$. granatum, $C$. officinalis, $H$. annuus, $O$. europaea were purchased from Mecidefendi firm., and the fresh oil of their seeds were provided by cold pressing machine. The chemical characterization of the oils were carried out in the Mersin University Advanced Technology Education Research and Application Center (MEU-MEITAM) by GC-FID analysis. The oils were stored $4^{\circ} \mathrm{C}$ in the dark before their employment in the following tests.

\section{GC-FID Analysis}

The oils were converted into corresponding fatty acid (FA) methyl esters according to Jennings and Akoh's work (2001). The GC-FID analysis was carried out on an Agient gas chromatograph equipped with a flame ionization detector (FID) and a data handling processor. The separation was achieved using an HP Innowax capillary column $(30 \mathrm{~m} * 0.25 \mathrm{~mm} * 0.25 \mu \mathrm{m}$ film thickness), helium as carrier gas $(20 \mathrm{~cm} / \mathrm{sec})$. Column temperature: $40^{\circ} \mathrm{C}$ with $5 \mathrm{~min}$ initial hold, and then to $140^{\circ} \mathrm{C}$ at $10^{\circ} \mathrm{C} / \mathrm{min}$, and then to $250^{\circ} \mathrm{C}$ after $15 \mathrm{~min}$; injection mode $1 \mu \mathrm{L}, 280^{\circ} \mathrm{C}$, split $100: 1$, Injector and detector temperatures were $280^{\circ} \mathrm{C}$ 
and $330^{\circ} \mathrm{C}$, respectively. The results were compared with CLnA, and FAME (Fatty acid methyl esters) standards (Sigma-Aldrich-supelco)

\section{Antimicrobial Screening (MIC, FIC and FICI)}

The combined antimicrobial activity of $O$. europaea, $P$. granatum, $C$. officinalis, $H$. annuus were researched on several pathogens, namely Escherichia coli (ATCC 25293), Enterococcus faecalis, Staphylococcus aureus (ATCC 25925), Bacillus subtilis (ATCC 6633), Candida albicans and Candida parapsilosis using modified spectrophotometric checkerboard microdilution technique. The inoculums of microorganisms were prepared in $4 \mathrm{ml}$ Triptic Soy Broth for bacteria, $4 \mathrm{ml}$ Sabouraud Dextrose Broth for yeasts and incubated at $37^{\circ} \mathrm{C}$, overnight. After 24 hours, the culture suspensions were adjusted to 0.5 McFarland Standard Turbidity $\left(\sim 10^{4}\right.$ for bacteria, $\left(\sim 10^{3}\right.$ for yeasts) and stored at $+4^{\circ} \mathrm{C}$ until use (McFarland, 1987). Cold-pressed oil of the plants were dissolved at $50 \mu 1 / \mathrm{ml}(6.8 \mathrm{mg} O$. europaea, $42.5 \mathrm{mg} P$. granatum, $3.5 \mathrm{mg}$ C. officinalis, $40.8 \mathrm{mg} H$. annuus) with dimethyl sulfoxide (10\% DMSO). The experiment were performed on 96-well microtiter plates and firstly $50 \mu 1$ of Mueller Hinton Broth (MHB) medium were added into all wells. Two-fold serial dilutions of $25 \mu 1$ solution of $P$. granatum or $C$. officinalis or H. annuus oil was made (A1-H1) on the $\mathrm{y}$-axis along of chequerdoard plate. Two-fold serial dilutions of $(50 \mu \mathrm{l}) O$. europaea was made $\mathrm{x}$-axis along from 2 nd to 10 th columns and $P$. granatum or $C$. officinalis or $H$. annuus solution (single concentration) was added to each well to make fraction and obtain the FIC final concentrations. Columns 11 and 12 were used as negative (medium) and positive (ampicillin for bacteria and fluconazole for yeast) controls, respectively. These standard antibiotics inhibited microorganisms at all concentration more than 16 $\mu \mathrm{g} / \mathrm{mL}$. Finally, $10 \mu \mathrm{L}$ culture of microorganisms was inoculated on all wells except negative control.

All the plates were incubated at $37^{\circ} \mathrm{C}$ for 24 hours, the growth (turbidity) was measured at $600 \mathrm{~nm}$ for bacteria, $415 \mathrm{~nm}$ for yeasts. For MIC analysis, the optical density was read both before, T0 and after 24 hours-incubation, T24. For each plate, MIC were calculated using the following formula: The OD for each replicate at T0 was subtracted from the OD for each replicate at T24. The Percent growth $=($ ODtest $/ O D$ control $) \times 100$. Percent Inhibition $=$ $1-(\mathrm{OD}$ test well/OD of corresponding control well)x100 for each row of the 96-well plate. The dose-response curves obtained from plotting the linear of the concentration of the oils against the resulting percent inhibition of microbial growth were obtained with the regression analysis, giving an R2 value. MIC (the lowest concentration of test material which results in $99,9 \%$ inhibition of growth) were calculated using the R2 formula on inhibition curve. For each plate, FIC and FICI (Fractional Inhibitory Concentration Index) were calculated using the following formula: all wells of the microtitration plates that corresponded to an MIC, the sum of the FICs ( $\mathrm{FIC}$ ) was calculated for each well with the equation;

$\Sigma \mathrm{FIC}=\mathrm{FIC}_{\mathrm{O}(\text { o. europaea })}+\mathrm{FIC}_{\mathrm{P}(\text { P. granatum })}=\left(\mathrm{MIC}_{(\mathrm{O}+\mathrm{P}) / \mathrm{O})}\right)+\left(\mathrm{MIC}_{(\mathrm{O}+\mathrm{P}) / \mathrm{P}}\right)$, $\Sigma \mathrm{FIC}=\mathrm{FIC}_{\mathrm{O}(\text { o. europaea })}+\mathrm{FIC}_{\mathrm{C}(\text { c. officinali })}=\left(\mathrm{MIC}_{(\mathrm{O}+\mathrm{C}) / \mathrm{O}}\right)+\left(\mathrm{MIC}_{(\mathrm{O}+\mathrm{C}) / \mathrm{C}}\right)$,
$\Sigma \mathrm{FIC}=\mathrm{FIC}_{\mathrm{O}(\text { O. europaea })}+\mathrm{FIC}_{\mathrm{H}(\text { H. annuи })}=\left(\mathrm{MIC}_{(\mathrm{O}+\mathrm{H}) / \mathrm{O}}\right)+\left(\mathrm{MIC}_{(\mathrm{O}+\mathrm{H}) / \mathrm{H}}\right)$,

where $\mathrm{MIC}_{\mathrm{O}}$ and $\mathrm{MIC}_{\mathrm{P}}, \mathrm{MIC}_{\mathrm{C}}, \mathrm{MIC}_{\mathrm{H}}$ are the MICs of O. europaea and the oils of $P$. granatum or $C$. officinalis or $H$. annuus alone, in all wells corresponding to an MIC (isoeffective combinations) (Erdogan Eliuz and Sicak 2018; Stergiopoulou et al. 2008). In present study, FICI values were interpreted following the conventional model suggested by Odds's work; According to that, a synergistic effect (SynE) is observed when FICI value $\leq 0.5$; an indifferent effect (IndE) when $0.5<\mathrm{FICI} \leq 4$ and an antagonistic effect (AntE) when FICI value>4 (Odds 2003).

\section{Statistical Analysis}

Statistical analyses and significance were measured by Tukey or Dunnet (2sided) test in one-way analysis of variance for MICs using SPSS 25. The experiment was repeated at least 3 times. Differences were considered significant at $\mathrm{p} \leq 0.05$.

\section{RESULTS AND DISCUSSION}

\section{Chemical Composition}

The components of fatty acid extracted from $O$. europaea, $P$. granatum, $C$. officinalis and $H$. annuus seeds with their retention time (Rt) and area (\%) were listed in Table 1. The O. europaea oil was abundant in oleic acid (73.65\%), palmitic acid $(12.86 \%)$, linoleic acid $(7.37 \%)$, stearic acid $(3.12 \%)$, palmitoleic acid $(1.05 \%)$, and trace amounts less than $1 \%$ with aracidic acid $(0.47 \%)$, n9-cis11-eicosenoic acid $(0.31 \%)$, behenic acid $(0.06 \%)$. The major FAs in $C$. officinalis oil were linolenic $(78.82 \%)$, oleic $(10.67 \%)$, palmitic acid $(6.49 \%)$ acids, stearic acid (1.82\%), and trace amounts less than $1 \%$ with aracidic acid $(0.22 \%)$, n9-cis-11-eicosenoic acid $(0.2 \%)$, palmitoleic acid $(0.15 \%)$, behenic acid $(0.12 \%)$, lauric acid $(0.1 \%)$, in $H$. annuus oil were linolenic $(50.25 \%)$, oleic $(36.97 \%)$, palmitic acid $(6.74 \%)$, stearic acid $(4.62 \%)$, and trace amounts less than $1 \%$ with behenic acid $(0.45 \%)$, aracidic acid $(0.22 \%)$, palmitoleic acid $(0.16 \%)$, n9-cis-11-eicosenoic acid $(0.13 \%)$, lauric acid $(0.07 \%)$ while in $P$. granatum oil were remarkably conjugated linolenic acids (CLnAs) (62.08\%), oleic acid $(8.35 \%)$, linoleic acid $(7.34 \%)$, palmitic acid $(4.11 \%)$ acids, stearic acid (2.90), n9-cis-11-eicosenoic acid (1.01\%), and trace amounts less than $1 \%$ with aracidic acid $(0.7 \%)$.

The results about chemical composition of the plants in this report compared with previous reports in literature and found that they are essentially similar. It was revealed that linoleic, oleic, palmitic and stearic were to be main component of O. europaea (Andjelkovic et al., 2009), C. officinalis (Ashwlayan et al., 2018) and $H$. annuus (Flagella et al., 2002). By contrast, pomegranate seed oil contained more than $70 \%$ conjugated linolenic acids (CLnA), followed by linoleic acid, oleic acid, stearic and palmitic (Özgül-Yücel, 2005; Fadavi et al., 2006).

Table 1 Chemical composition of $O$. europaea, $P$. granatum, C. officinalis and $H$. annuus seed oil

\begin{tabular}{|c|c|c|c|c|c|c|c|c|}
\hline \multirow{2}{*}{ Fatty acids } & \multicolumn{2}{|c|}{ O. europaea } & \multicolumn{2}{|c|}{ C. officinalis } & \multicolumn{2}{|c|}{ H. annuus } & \multicolumn{2}{|c|}{ P. granatum } \\
\hline & $\mathbf{R a}$ & Rt & $\mathbf{R a}$ & Rt & \multicolumn{2}{|c|}{ Ra Rt } & \multicolumn{2}{|c|}{ Ra Rt } \\
\hline C12:0 lauric acid & - & - & 0.1 & 13.6 & 0.07 & 9.727 & - & - \\
\hline C16:0 palmitic acid & 12.86 & 12.340 & 6.49 & 12.289 & 6.74 & 12.279 & 4.11 & 12.254 \\
\hline C16:1 palmitoleic acid & 1.05 & 12.581 & 0.15 & 12.561 & 0.16 & 12.559 & - & - \\
\hline C18:0 stearic acid & 3.12 & 14.596 & 1.82 & 14.470 & 4.62 & 14.477 & 2.90 & 14.419 \\
\hline C18:1 oleic acid & 73.65 & 14.868 & 10.67 & 14.694 & 36.97 & 14.734 & 8.35 & 14.649 \\
\hline C18:2 linoleic acid & 7.37 & 15.199 & 78.82 & 15.287 & 50.25 & 15.225 & 7.34 & 15.112 \\
\hline C20:0 aracidic acid & 0.47 & 16.371 & 0.22 & 16.364 & 0.22 & 16.368 & 0.7 & 16.352 \\
\hline C20:1 n9 cis-11-eicosenoic acid & 0.31 & 16.592 & 0.2 & 16.586 & 0.13 & 16.590 & 1.01 & 16.574 \\
\hline CLnA (Conjuge linolenic acid ) & - & - & - & - & - & - & 62.08 & 18.087 \\
\hline C22:0 behenic acid & 0.06 & 18.626 & 0.12 & 18.614 & 0.45 & 18.626 & - & - \\
\hline Total & \multicolumn{2}{|l|}{$98.89 \%$} & \multicolumn{2}{|c|}{$98.59 \%$} & \multicolumn{2}{|c|}{$99.61 \%$} & \multicolumn{2}{|c|}{$86.49 \%$} \\
\hline
\end{tabular}

Legend: Ra: Relative abundance (\%), Rt: Retention time

\section{Antimicrobial Activity and Evaluation of FICI Values}

The antimicrobial activity of E. coli, E. faecalis, S. aureus, B. subtilis, C. albicans and $C$. parapsilosis to single and combinations with $O$. europaea oil of fatty acids of $P$. granatum, $C$. officinalis, $H$. annuus to detect synergistic effect (SynE) or indifferent effect (IndE) or antagonistic effect (AntE) were showed on Table 2. Strong antimicrobial activity alone were noticed for the oils of $O$. europaea $(26-158.4 \mu \mathrm{g} / \mathrm{mL})$, C. officinalis $(23.4-44.8 \mu \mathrm{g} / \mathrm{mL})$, H. annuus $(15.7-$ $211.6 \mu \mathrm{g} / \mathrm{mL}), P$. granatum $(48.2-389.25 \mu \mathrm{g} / \mathrm{mL})$. 
Table 2 MIC $(\mu \mathrm{g} / \mathrm{mL})$ values of $O$. europaea $(\mathrm{O})$ alone or in combinations with P. granatum (P), C. officinalis (C), H. Annuus (H) and FICI values of the combination of them with E. coli, E. faecalis, S. aureus, B. subtilis, C. albicans and C. parapsilosis.

\begin{tabular}{|c|c|c|c|c|c|c|c|c|c|c|c|c|}
\hline & \multicolumn{2}{|c|}{ E.c. } & \multicolumn{2}{|c|}{$E . f$} & \multicolumn{2}{|l|}{$S a$} & \multicolumn{2}{|l|}{ B.s } & \multicolumn{2}{|c|}{ C.a } & \multicolumn{2}{|c|}{ C.p } \\
\hline & MIC & FICI & MIC & FICI & MIC & FICI & MIC & FICI & MIC & FICI & MIC & FICI \\
\hline Od & $54.0^{\mathrm{a}}{ }_{ \pm 12.4}$ & - & $164.1_{ \pm 31.2}$ & - & $149.7_{ \pm 9.9}$ & $\begin{array}{l}- \\
-\end{array}$ & $158.4^{\mathrm{de}}{ }_{ \pm 62.8}$ & - & $28.5_{ \pm 6.4}$ & - & $26_{ \pm 2.8}$ & - \\
\hline $\mathrm{Cd}$ & $39.07_{ \pm 3.1}^{\mathrm{a}}$ & - & $34.4_{ \pm 6.9}^{\mathrm{b}}$ & & $44.8_{ \pm 4.5}$ & - & $24.3^{\mathrm{c} \mathrm{def}}{ }_{ \pm 6.4}$ & - & $23.4_{ \pm 5.4}$ & - & $23.9_{ \pm 3.4}$ & \\
\hline $\mathrm{Hd}$ & $36.3^{\mathrm{a}}{ }_{ \pm 13.2}$ & - & $56.3_{ \pm 18.0}$ & & $15.9_{ \pm 1.5}$ & - & $117.1_{ \pm 77.1}^{\mathrm{de}}$ & - & $211.6_{ \pm 59.4}$ & - & $15.7_{ \pm 1.1}$ & - \\
\hline $\mathrm{Pd}$ & $389.25_{ \pm 20.5}$ & - & $48.2_{ \pm 9.5}$ & - & $101.9_{ \pm 3.6}$ & - & $48.4^{\mathrm{de}}{ }_{ \pm 7.4}$ & - & $60.3_{ \pm 20.4}$ & - & $70.5_{ \pm 30.4}$ & - \\
\hline $\mathrm{Od}+\mathrm{C}_{100}$ & $32.1^{\mathrm{a}} \pm 10.5$ & 1.3 & $118.5_{ \pm 22.4}$ & 6.5 & $52.9_{ \pm 2.5}$ & 1.4 & $391.6^{\mathrm{d}}{ }_{ \pm 88.1}$ & 18.07 & $93.2_{ \pm 31.8}$ & 6.3 & $68.4_{ \pm 55.5}$ & 5.6 \\
\hline $\mathrm{Od}+\mathrm{H}_{100}$ & $33.3^{\mathrm{a}} \pm 10.2$ & 2.2 & $154.8_{ \pm 39.5}$ & 5.8 & $27.9_{ \pm 3.2}$ & 2.04 & $99.2_{ \pm 88.4}^{\mathrm{de}}$ & 1.3 & $39.6_{ \pm 11.4}$ & 2.7 & $26.8_{ \pm 3.2}$ & 3.4 \\
\hline $\mathrm{Od}+\mathrm{P}_{100}$ & $79.28_{ \pm 12.1}$ & 1.4 & $62.70_{ \pm 12.5}$ & 1.4 & $378.1_{ \pm 12.4}$ & 6.9 & $139.5^{\mathrm{de}}{ }_{ \pm 2.5}$ & 5.1 & $31.12_{ \pm 11.8}$ & 1.7 & $27.8_{ \pm 8.4}$ & 1.1 \\
\hline $\mathrm{Od}+\mathrm{C}_{50}$ & $49.9^{\mathrm{a}}{ }_{ \pm 11.4}$ & 2.02 & $100.04_{ \pm 11.4}$ & 5.5 & $37.36_{ \pm 7.5}$ & 0.9 & $109.02^{\mathrm{de}}{ }_{ \pm 75.2}$ & 5.03 & $41.4_{ \pm 22.1}$ & 2.8 & $42.8_{ \pm 11.4}$ & 3.5 \\
\hline $\mathrm{Od}+\mathrm{H}_{50}$ & $228.7_{ \pm 12.1}$ & 15.3 & $105.8_{ \pm 9.8}$ & 3.9 & $56.9_{ \pm 2.5}$ & 4.1 & $82.2^{\mathrm{de}}{ }_{ \pm 82.1}$ & 1.08 & $35.7_{ \pm 11.1}$ & 2.4 & $38.67_{ \pm 6.2}$ & 4.9 \\
\hline $\mathrm{Od}+\mathrm{P}_{50}$ & $51.8^{\mathrm{a}}{ }_{ \pm 15.1}$ & 0.9 & $29.9_{ \pm 3.4}$ & 0.6 & $173.2_{ \pm 4.5}$ & 3.1 & $45.2^{\mathrm{cde}} \pm 6.4$ & 1.6 & $24.2_{ \pm 2.3}$ & 1.3 & $44.07_{ \pm 22.1}$ & 1.7 \\
\hline $\mathrm{Od}+\mathrm{C}_{25}$ & $61.01^{\mathrm{a}}{ }_{ \pm 16.3}$ & 2.4 & $126.3_{ \pm 22.7}$ & 6.9 & $28.1_{ \pm 2.8}$ & 0.7 & $507.5_{ \pm 39.7}$ & 23.4 & $32.9_{ \pm 14.4}$ & 2.2 & $15.9_{ \pm 10.0}$ & 1.3 \\
\hline $\mathrm{Od}+\mathrm{H}_{25}$ & $172.1_{ \pm 21.5}$ & 11.5 & $41.3_{ \pm 9.4}$ & 1.5 & $31.3_{ \pm 3.1}$ & 2.2 & $93.8^{\mathrm{de}}{ }_{ \pm 22.2}$ & 1.2 & $42.5_{ \pm 9.5}$ & 2.9 & $342.2_{ \pm 88.4}$ & 44.01 \\
\hline $\mathrm{Od}+\mathrm{P}_{25}$ & $69.5_{ \pm 14.4}$ & 1.2 & $30.4^{\mathrm{b}}{ }_{ \pm 8.5}$ & 0.7 & $84.8_{ \pm 4.7}$ & 1.5 & $26.8^{\mathrm{c} \mathrm{def}}=11.3$ & 0.9 & $21.3_{ \pm 1.9}$ & 1.1 & $0.4_{ \pm 1.3}$ & 0.01 \\
\hline $\mathrm{Od}+\mathrm{C}_{12.5}$ & $31.7^{\mathrm{a}}{ }_{ \pm 8.4}$ & 1.2 & $1550_{ \pm 39.8}$ & 85.7 & $26.6_{ \pm 4.4}$ & 0.7 & $88.2^{\mathrm{de}}{ }_{ \pm 10.9}$ & 4.07 & $19.2_{ \pm 6.4}$ & 1.3 & $53.2^{\mathrm{h}}{ }_{ \pm 12.4}$ & 4.3 \\
\hline $\mathrm{Od}+\mathrm{H}_{12.5}$ & $100.6_{ \pm 26.1}$ & 6.7 & $71.9_{ \pm 5.6}$ & 2.7 & $51.08_{ \pm 6.4}$ & 3.7 & $46.4^{\mathrm{de}}{ }_{ \pm 18.4}$ & 0.6 & $92.03_{ \pm 30.4}$ & 6.3 & $153.3_{ \pm 21.8}$ & 19.7 \\
\hline $\mathrm{Od}+\mathrm{P}_{12.5}$ & $45.06^{\mathrm{a}}{ }_{ \pm 4.1}$ & 0.8 & $216.6_{ \pm 8.8}$ & 5.02 & $247.9_{ \pm 18.9}$ & 4.5 & $145.3^{\mathrm{de}}{ }_{ \pm 88.1}$ & 5.3 & $17.8_{ \pm 12.5}$ & 0.9 & $49.4_{ \pm 13.4}$ & 2.00 \\
\hline $\mathrm{Od}+\mathrm{C}_{6.25}$ & $39.2^{\mathrm{a}}{ }_{ \pm 3.5}$ & 1.5 & $284.01_{ \pm 41.7}$ & 15.7 & $25.82_{ \pm 2.1}$ & 0.6 & $164.3^{\mathrm{de}}=36.5$ & 7.5 & $27.8_{ \pm 4.7}$ & 1.9 & $73.69_{ \pm 28.1}$ & 6.05 \\
\hline $\mathrm{Od}+\mathrm{H}_{6.25}$ & $110.8_{ \pm 31.1}$ & 7.4 & $52.5_{ \pm 9.8}$ & 1.9 & $79.5_{ \pm 3.4}$ & 5.8 & $61.8^{\mathrm{de}}{ }_{ \pm 12.4}$ & 0.8 & $58.17_{ \pm 11.5}$ & 4.01 & $905.01_{ \pm 66.7}$ & 116.4 \\
\hline $\mathrm{Od}+\mathrm{P}_{6.25}$ & $77.11_{ \pm 12.3}$ & 1.4 & $45.6_{ \pm 4.5}$ & 1.05 & $48.9_{ \pm 7.1}$ & 0.8 & $26.2^{\mathrm{c} \mathrm{deg}}{ }_{ \pm 2.4}$ & 0.2 & $16.05_{ \pm 5.4}$ & 0.8 & $41.3_{ \pm 16.3}$ & 1.6 \\
\hline $\mathrm{Od}+\mathrm{C}_{3.125}$ & $51.14^{\mathrm{a}}{ }_{ \pm 16.4}$ & 2.07 & $156.7_{ \pm 29.4}$ & 8.6 & $24.4_{ \pm 1.4}$ & 0.6 & $635.9_{ \pm 87.1}$ & 29.3 & $37.4_{ \pm 29.4}$ & 2.5 & $919.9_{ \pm 100.4}$ & 75.5 \\
\hline $\mathrm{Od}+\mathrm{H}_{3.125}$ & $63.5_{ \pm 26.7}^{\mathrm{a}}$ & 4.2 & $524.7_{ \pm 44.5}$ & 19.7 & $25.6_{ \pm 1.9}$ & 1.8 & $106.9^{\mathrm{de}}{ }_{ \pm 66.4}$ & 1.4 & $107.04_{ \pm 49.1}$ & 7.3 & $70.7_{ \pm 30.7}$ & 9.09 \\
\hline $\mathrm{Od}+\mathrm{P}_{3.125}$ & $61.9^{\mathrm{a}}{ }_{ \pm 14.3}$ & 1.1 & $61.8^{\mathrm{b}}{ }_{ \pm 8.5}$ & 1.4 & $43.8_{ \pm 2.5}$ & 0.8 & $26.6^{\mathrm{cde}}{ }_{ \pm 10.1}$ & 0.9 & $16.8_{ \pm 1.4}$ & 0.9 & $32.08_{ \pm 17.6}$ & 1.3 \\
\hline $\mathrm{Od}+\mathrm{C}_{1.56}$ & $154.6_{ \pm 25.4}$ & 6.2 & $81.9_{ \pm 9.8}$ & 4.5 & $41.3_{ \pm 4.4}$ & 1.09 & $78.4^{\mathrm{de}}{ }_{ \pm 12.4}$ & 3.6 & $39.4_{ \pm 5.9}$ & 2.6 & $50.4_{ \pm 14.8}$ & 4.1 \\
\hline $\mathrm{Od}+\mathrm{H}_{1.56}$ & $56.8^{\mathrm{a}}{ }_{ \pm 10.9}$ & 3.8 & $65.1_{ \pm 7.9}$ & 2.4 & $27.08_{ \pm 6.5}$ & 1.9 & $56.9^{\mathrm{de}}{ }_{ \pm 13.2}$ & 0.7 & $277.4_{ \pm 44.1}$ & 19.1 & $25.09_{ \pm 2.8}$ & 3.2 \\
\hline $\mathrm{Od}+\mathrm{P}_{1.56}$ & $91.46_{ \pm 24.3}$ & 1.6 & $254.2_{ \pm 19.5}$ & 5.9 & $286.01_{ \pm 66.9}$ & 5.2 & $20.9^{\text {cdefg }} \pm 5.4$ & 0.7 & $37.6_{ \pm 6.6}$ & 2.1 & $94.02_{ \pm 22.6}$ & 3.8 \\
\hline
\end{tabular}

Statistically, the mean MICs were expressed with the $\mathrm{SD}( \pm)$ and $(\mathrm{p}<0.05)$. D:Dunnet $(2$-sided), T: Tukey, (T), d: 2 -fold dilution. According to the test, a: shows the difference from the (Pd) fraction $(\mathrm{T})$ in E.coli, b: shows the difference from the $\left(\mathrm{Od}+\mathrm{C}_{25}\right)$ fraction (D) in E. fecalis, c: shows the difference from the $\left(\mathrm{Od}+\mathrm{C}_{100}\right)$ fraction $(\mathrm{T})$ in $B$. subtilis, $\mathbf{d}$ : shows the difference from the $\left(\mathrm{Od}+\mathrm{C}_{25}\right)$ fraction $(\mathrm{T})$ in $B$. subtilis, e: shows the difference from the $\left(\mathrm{Od}+\mathrm{C}_{3.125}\right)$ fraction $(\mathrm{T})$ in $B$. subtilis, f: shows the difference from the $\left(\mathrm{Od}+\mathrm{C}_{12.5}\right)$ fraction $(\mathrm{D})$ in B. subtilis, $\mathbf{g}$ : shows the difference from the $\left(\mathrm{Od}+\mathrm{H}_{6.25}\right)$ fraction (D) in B. subtilis, $\mathbf{h}$ : shows the difference from the $\left(\mathrm{Od}+\mathrm{P}_{25}\right)$ fraction $(\mathrm{D})$ in $C$. parapsilosis $(\mathrm{n}=3)$.

The MIC results of the oils of olive, safflower, sunflower and pomegranate alone were $54.0 \mu \mathrm{g} / \mathrm{mL}, 39.07 \mu \mathrm{g} / \mathrm{mL}, 36.3 \mu \mathrm{g} / \mathrm{mL}, 389.25$ for E. coli, $164.1 \mu \mathrm{g} / \mathrm{mL}$ $44.8 \mu \mathrm{g} / \mathrm{mL}, 56.3 \mu \mathrm{g} / \mathrm{mL}, 48.2 \mu \mathrm{g} / \mathrm{mL}$ for E. faecalis, $149.7 \mu \mathrm{g} / \mathrm{mL}, 44.8$ $\mu \mathrm{g} / \mathrm{mL}, 15.9 \mu \mathrm{g} / \mathrm{mL}, 101.9 \mu \mathrm{g} / \mathrm{mL}$ for $S$. aureus, $158.4 \mu \mathrm{g} / \mathrm{mL}, 24.3 \mu \mathrm{g} / \mathrm{mL}$, $117.1 \mu \mathrm{g} / \mathrm{mL}, 48.4 \mu \mathrm{g} / \mathrm{mL}$ for B. subtilis, $28.523 .4 \mu \mathrm{g} / \mathrm{mL}, 211.6 \mu \mathrm{g} / \mathrm{mL}, 60.3$ $\mu \mathrm{g} / \mathrm{mL}$ for C. albicans and $26 \mu \mathrm{g} / \mathrm{mL}, 23.9 \mu \mathrm{g} / \mathrm{mL}, 15.7 \mu \mathrm{g} / \mathrm{mL}, 70.5 \mu \mathrm{g} / \mathrm{mL}$ for $C$. parapsilosis, respectively.

The present study was shown that $O$. europaea, C. officinalis, H. annuus, $P$. granatum oils alone were potentially rich source of antimicrobial agent and inhibited the pathogens (E. coli, B. subtilis, S. aureus, E. fecalis, C. albicans, and $C$. parapsilosis) at more concentration of $15.7 \mu \mathrm{g} / \mathrm{mL}$. According to the study of Janakat et al., (2015), MIC and minimum bactericidal (MB) concentrations of the methanolic extract of olive oil lees was determined against $L$. monocytogenes, S. aureus, E. coli and S. enteritidis at a ranged from 60 to $80 \mu \mathrm{l} / \mathrm{ml}$ after $24 \mathrm{~h}$ incubation. The IC25 values of olive leaf aqueous extracts were found for microbial growth rate of B. cereus, B. subtilis, S. aureus, E. coli, P. aeruginosa, $K$. pneumoniae, $C$. albicans, and $C$. neoformans at a range of $0.1-5 \mathrm{mg} / \mathrm{m}$ (Pereira et al., 2007). The commercial leaf extract of Olea europaea was found to be most active against Campylobacter jejuni, Helicobacter pylori and MRStaphylococcus aureus with MICs as low as $0.31-0.78 \%$ (v/v) (Sudjana et al., 2009). Holetz et al., (2002) reported that $P$. granatum oil was effective even at a very low concentration $(62.5 \mu \mathrm{g} / \mathrm{mL})$ on $S$. aureus. In the same study, high antifungal activity was observed against $C$. parapsilosis $(12.5 \mu \mathrm{g} / \mathrm{mL})$. Compared with present study, both $S$. aureus $(101.9 \mu \mathrm{g} / \mathrm{mL})$ and $C$. parapsilosis $(70.5$ $\mu \mathrm{g} / \mathrm{mL}$ ) are inactivated at lower concentrations. Pai et al., (2010) calculated the antimicrobial activity of $P$. granatum seed oil against $C$. albicans at $18.8 \mu \mathrm{g} / \mathrm{mL}$. The importance of CLnA in the antimicrobial activity of pomegranate is significant (Wang et al., 2007).

In a study which reported antifungal activity of Helianthus annuus seed extract $(50 \mu \mathrm{g} / \mathrm{mL})$ was showed moderate activity to Staphylococcus aureus $(1.2 \mathrm{~cm})$ and Candida albicans $(1.0 \mathrm{~cm}$ ) by agar well diffusion method (Subashini and Rakshitha, 2012). Aziz et al., (1998) reported that the polar oil extract of $H$. annuиs seed in presence of Zinc have shown the highest rate antimicrobial activity on Staphylococcus aureus followed by Pseudomonas aeruginosa, Escherichia coli, Proteus vulgaris and Candida albicans. C. officinalis has already shown to be effective against $E$. coli, B. subtilis, $P$. aeruginosa, Salmonella typhi and Staphylococcus aureus at more concentration of $0.01 \mu \mathrm{g} / \mathrm{mL}$ (Pandey and Chandel, 2014). Likewise, it was noted that $C$. officinalis tincture
$60 \%(\mathrm{v} / \mathrm{v})$ ethanol was an important antibacterial agent for Pseudomonas aeruginosa (Mabuza, 2018)

When the antimicrobial activities of combinations with $O$. europaea oil of fatty acids of $P$. granatum, $C$. officinalis, $H$. annuus were examined, the values of the MICs in all fractions with olive of safflower, sunflower and pomegranate were found is statistically different $(p \leq 0.05)$ from the MICs determined from the plant's alone against pathogen microorgnisms in this study. The lowest MIC value were reported as $31.7 \mu \mathrm{g} / \mathrm{mL}$ in the fraction with $\mathrm{Od}+\mathrm{C}_{12.5}$, while the highest MIC was $389.25 \mu \mathrm{g} / \mathrm{mL}$ in Pd against E. coli. While the lowest MIC value were reported as $29.9 \mu \mathrm{g} / \mathrm{mL}$ in the fraction with $\mathrm{Od}+\mathrm{P}_{50}$, the highest MIC was $1550 \mu \mathrm{g} / \mathrm{mL}$ in $\mathrm{Od}+\mathrm{C}_{12.5}$ against $E$. fecalis. The lowest MIC value were reported as $25.6 \mu \mathrm{g} / \mathrm{mL}$ in the fraction with $\mathrm{Od}+\mathrm{H}_{3,125}$, while the highest MIC was $378.1 \mu \mathrm{g} / \mathrm{mL}$ in $\mathrm{Od}+\mathrm{P}_{100}$ against $S$. aureus, while the lowest MIC value were reported $20.9 \mu \mathrm{g} / \mathrm{mL}$ in the fraction with $\mathrm{Od}+\mathrm{H}_{3.125}$, the highest MIC was $635.9 \mu \mathrm{g} / \mathrm{mL}$ in $\mathrm{Od}+\mathrm{C}_{3.125}$ against $B$. subtilis. For the yeast, the lowest MIC value were reported as $16.8 \mu \mathrm{g} / \mathrm{mL}$ in the fraction with $\mathrm{Od}+\mathrm{P}_{3.125}$, while the highest MIC was $277.4 \mu \mathrm{g} / \mathrm{mL}$ in $\mathrm{Od}+\mathrm{H}_{1.56}$ against $C$. albicans. Finally, the lowest MIC value were reported as $0.4 \mu \mathrm{g} / \mathrm{mL}$ in the fraction with $\mathrm{Od}+\mathrm{P}_{25}$, while the highest MIC was $919.9 \mu \mathrm{g} / \mathrm{mL}$ in $\mathrm{Od}+\mathrm{C}_{3.125}$ against $C$. parapsilosis.

Antimicrobial activities of some fractions $P$. granatum, $C$. officinalis and $H$. annuиs with $O$. europaea was found to be significantly different from other some fractions $(\mathrm{p}<0.05)$. For example, the MIC of $\mathrm{Cd}(34.4 \mu \mathrm{g} / \mathrm{mL})$, $\mathrm{Od}+\mathrm{P}_{25}(30.4 \mu \mathrm{g} / \mathrm{mL})$ and $\mathrm{Od}+\mathrm{P}_{3.125}(61.8 \mu \mathrm{g} / \mathrm{mL})$ were found to be higher than MIC of Od+C 25 fraction $(126.3 \mu \mathrm{g} / \mathrm{mL}$ ) against $E$. fecalis $(\mathrm{p}<0.05)$. The MIC of $\mathrm{Od}+\mathrm{P}_{50}(45.2 \mu \mathrm{g} / \mathrm{mL})$ and $\mathrm{Od}+\mathrm{P}_{25}(26.8 \mu \mathrm{g} / \mathrm{mL})$ significantly different from the MIC of $\mathrm{Od}+\mathrm{C}_{100}$ fraction $(391.6 \mu \mathrm{g} / \mathrm{mL})$ against $B$. subtilis. In addition, the MIC of Od+C $\mathrm{C}_{125}(53.2 \mu \mathrm{g} / \mathrm{mL})$ were found to be lower than MIC of Od+ $\mathrm{P}_{25}$ fraction $(0.4 \mu \mathrm{g} / \mathrm{mL})$ against $C$. parapsilosis.

Despite of the oil of $P$. granatum alone were found to be low antimicrobial potential, its fractions with $O$. europaea changed as increase its MIC alone against $E$. coli. The MIC of pomegranate oil alone was found as 389.25 $\mu \mathrm{g} / \mathrm{mL}$, while some fractions with olive oil such as $\mathrm{Od}+\mathrm{P}_{100}, \mathrm{Od}+\mathrm{P}_{50}, \mathrm{Od}+\mathrm{P}_{12.5}$ were found as $32.1 \mu \mathrm{g} / \mathrm{mL}, 51.8 \mu \mathrm{g} / \mathrm{mL}$ and $45.06 \mu \mathrm{g} / \mathrm{mL}$, respectively, against $E$. coli. In contrast, the MIC value of $\mathrm{C}_{\mathrm{d}}$ fraction $(24.3 \mu \mathrm{g} / \mathrm{mL})$ against $B$. subtilis were to decrease with the using $\mathrm{Od}+\mathrm{C}_{50}(109.02 \mu \mathrm{g} / \mathrm{mL})$.

The most common in vitro technique for detecting interactions between oils and antibiotics or other oils is the checkerboard technique (Lv et al., 2011). Using 
this technique, researches were done about combinations of drugs occurred strong antimicrobial effect on the some microorganisms species. Singh et al., (2015) were determined that the combinations of ethanolic and fruits (Calendula officinalis: Carissa: Mentha 1:2:1) showed strong antimicrobial activity agains $B$. cereus and $S$. aureus. In the study which antibacterial activities of combination of oleic acid and gentamicin against Staphylococcus aureus (including meticillin-resistant:MRSA), synergetic effect were reported (Atashbeyk et al., 2014). The linoleic and oleic acid extracted from Helichrysum pedunculatum combinations were inactive against the Gram-negative species, while synergistic effect was observed against Staphylococcus aureus and Micrococcus kristinae (Dilika et al., 2000).

According to the findings of this results, the interaction data in the form of the fractional inhibitory concentration indices (FICIs) were listed in Table 2. According to the current study, exposing microorganisms to olive oil and safflower or sunflower or pomegranate combinations overnight, mostly AntE or IndE were occured between $23 \%$ and $77 \%$ for all the pathogens. Remarkable IndE was observed as $71.43 \%$ against E.coli and $76.19 \%$ against $S$. aureus, B.subtilis, C.albicans while lower AntE noted as $28.57 \%$ against E.coli and $23.81 \%$ against S.aureus, B.subtilis, C.albicans (FICI range of 0.6 to 23.4) AntE and IndE were noted $52.38 \%$ and $47.62 \%$ for E.fecalis (FICI range of 0.67 to 85.7 ),respectively. Interestingly, low level of SynE (4.76\%), equally level of AntE and IndE (47.62\%) were reported against C.parapsilosis (FICI range of 0.01 to 116.4 ) in this study (Figure 1 ).

\section{FICI values \%}

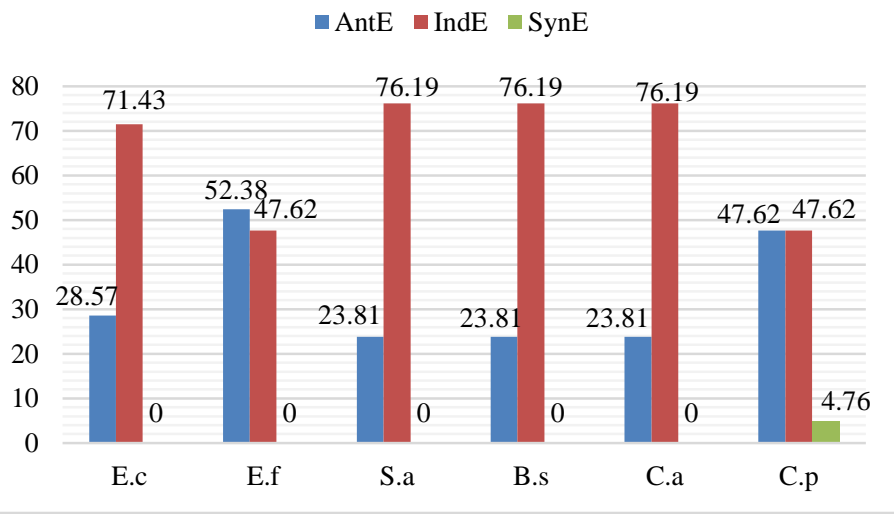

Figure 1 Percentage of FICI values of $O$. europaea alone or in combinations with $P$. Granatum, C. Officinali, $H$. Annuus and FICI values of the combination of them with E. coli, E. faecalis, S. aureus, B. subtilis, C. albicans and $C$. parapsilosis by 24 hours of incubation. Antagonistic: Ant, synergistic: Syn, Indifferent: Ind Effect.

It is claimed that fatty acids have more antagonistic effects on Gram-positive than Gram-negative bacteria (Branen et al., 1980; Russell, 1991). In present study, remarkable IndE was observed as $71.43 \%$ against E.coli and $76.19 \%$ against $S$ aureus, B.subtilis, C.albicans while lower AntE noted as $28.57 \%$ against E.coli and $23.81 \%$ against S.aureus, B.subtilis, C.albicans (FICI range of 0.6 to 23.4). AntE and IndE were noted $52.38 \%$ and $47.62 \%$ for E.fecalis (FICI range of 0.67 to 85.7 ), respectively. Interestingly, low level of SynE (4.76\%), equally level of AntE and IndE $(47.62 \%)$ were reported against C.parapsilosis (FICI range of 0.01 to 116.4). A synergistic effect was only observed in $C$. parapsilosis According to the obtained results, the combination of $O$. europaea with $C$. officinalis, $H$. annuus, $P$. granatum oils one by one showed mostly indifferent or antagonistic effect against six tested microorganisms.

\section{CONCLUSION}

This study indicates that the combination of fatty acid of olive and the three medicinal plants (safflower, sunflower and pomegranate) has significant potential for the development of new antimicrobial treatment, which will permit to find the treatment of many diseases caused by microorganisms. From the results obtained, the fatty acids of olive oil acts in mostly indifferent with the tested other medicinal plants oil. This interaction could lead to new aproaches in ethnomedicinal treatment of infectious diseases. Hence, there is a strong possibility that studies on the biochemical of the antagonist, indifferent and synergistic interactions between medicinal plants will improve in the long term.

Acknowledgments: This study was supported by Mersin University Scientific Research Projects Unit. (Project no: 2016-2-AP1-1918). Thanks to Cihan Geçgel (experts in MEITAM) for GC.

\section{REFERENCES}

Andjelkovic, M., Acun, S., Van Hoed, V., Verhé, R., and Van Camp, J. (2009). Chemical composition of Turkish olive oil - Ayvalik. Journal of the American Oil Chemists' Society, 86(2), 135-140. https://doi.org/10.1007/s11746-008-1330y

Artajo, L.S., Romero, M.P., Morelló, J.R., and Motılva, M.J. (2006). Enrichment of refined olive oil with phenolic compounds: Evaluation of their antioxidant activity and their effect on the bitter index. Journal of Agricultural and Food Chemistry, 54(16), 6079-6088

https://doi.org/10.1021/jf060874q

Ashwlayan, V.D., Kumar, A., Verma, M., Garg, V.K., and Gupta, S. (2018) Therapeutic Potential of Calendula officinalis. Pharmacy \& Pharmacology $\begin{array}{llr}\text { International } & \text { Journal, } & \text { 6(2), }\end{array}$ https://doi.org/10.15406/ppij.2018.06.00171

Atashbeyk, D.G., Khameneh, B., Tafaghodi, M., and Bazzaz, B.S.F. (2014) Eradication of methicillin-resistant Staphylococcus aureus infection by nanoliposomes loaded with gentamicin and oleic acid. Pharmaceutical Biology, 52(11), 1423-1428.

https://doi.org/10.3109/13880209.2014.895018

AzIz, N.H., Farag, S.E., Mousa, L.A., and Abo-ZaId, M.A. (1998). Comparative antibacterial and antifungal effects of some phenolic compounds. Microbios, 93(374), 43-54.

Branen, A.L., Davidson, P.M., and Katz, B. (1980). Antimicrobial properties of phenolic antioxidants and lipids. Food Technology, 34, 42-53.

Delaquis, P.J., Stanıch, K., Gırard, B., and Mazza, G. (2002). Antimicrobial activity of individual and mixed fractions of dill, cilantro, coriander and eucalyptus essential oils. International Journal of Food Microbiology, 74(12),101-9.

https://doi.org/10.1016/s0168-1605(01)00734-6

Dilika, F., Bremner, P.D., and Meyer, J.J.M. (2000). Antibacterial activity of linoleic and oleic acids isolated from Helichrysum pedunculatum: a plant used during circumcision rites. Fitoterapia, 71(4), 450-452. https://doi.org/10.1016/s0367-326x(00)00150-7

Erdoğan Elıuz, E.A., and Sicak, Y. (2018). Components and antimicrobial activity of essential oil of aerial parts of sage (Salvia officinalis L.). Journal of Ongoing Chemical Research, 3(2), 63-66.

Fadavi, A., Barzegar, M., and Hosseın Azızı, M. (2006). Determination of fatty acids and total lipid content in oilseed of 25 pomegranates varieties grown in Iran. Journal of Food Composition and Analysis, 19(6-7), 676-680. https://doi.org/10.1016/j.jfca.2004.09.002

Firestone, D. (2005). Pomegranate seed oil. In Bailey's Industrial Oil and Fat Products, Ed. Shahidi, F., John Wiley \& Sons: Canada America, pp. 255.

Flagella, Z., Rotunno, T., Tarantıno, E., Dı Caterına, R., and De Caro, A. (2002) Changes in seed yield and oil fatty acid composition of high oleic sunflower (Helianthus annuus L.) hybrids in relation to the sowing date and the water regime. European Journal of Agronomy, 17(3), 221-230. https://doi.org/10.1016/s1161-0301(02)00012-6

Gruenwald J, Brendler T, Jaenicke C, editors PDR. 2000. For Herbal Medicines. 2nd ed, Lovage. Levisticum officinale. Thompson Medical Economics, Montvale NJ,; pp 497-500.

Hammer, K.A., Carson, C.F., and Rileya, T.V. (2012). Effects of Melaleuca alternifolia (tea tree) essential oil and the major monoterpene component terpinen-4-ol on the development of single- and multistep antibiotic resistance and antimicrobial susceptibility. Antimicrobial Agents and Chemotherapy, 56(2), 909-15. https://doi.org/10.1128/aac.05741-11

Hemaiswarya, S., Kruthivent1, A.K., and Doble, M. (2008). Synergism between natural products and antibiotics against infectious diseases. Phytomedicine, 15(8), 639-52. https://doi.org/10.1016/j.phymed.2008.06.008

Holetz, F.B., Pessinı, G.L., Sanches, N.R., Cortez, D.A.G., Nakamura, C.V., Dias, and Filho, B.P. (2002). Screening of some plants used in the Brazilian folk medicine for the treatment of infectious diseases. Memórias do Instituto Oswaldo Cruz, 97(7), 1027-31.

https://doi.org/10.1590/s0074-02762002000700017

Janakat, S., Al-Nabulsı, A.A.R., Allehdan, S., Olaımat, A.N., and Holley, R.A. (2015). Antimicrobial activity of amurca (olive oil lees) extract against selected foodborne pathogens. Food Science and Technology, 35(2), 259-265. https://doi.org/10.1590/1678-457x.6508

Jennıngs, B.H., and Akoh, C.C. (2001). Lipase catalyzed modification of fish oil to incorporate capric acid. Food Chemistry, 72(3), 273-278.

https://doi.org/10.1016/S0308-8146(00)00266-1

Jurenka, J. (2008). Therapeutic applications of pomegranate (Punica granatum L.): A review. Alternative Medicine Review, 13(2), 128-44.

Kırbaşlar, F.G., Turker, G., Ozsoy-Gunes, Z., unal, M., Dulger, B., Ertas, E., and Kizılkaya, B. (2012). Evaluation of Fatty Acid Composition, Antioxidant and Antimicrobial Activity, Mineral Composition and Calorie Values of Some Nuts and Seeds from Turkey. Records of Natural Products, 6(4), 339-349.

Kon, K.V., and Rai, M.K. (2012). Plant essential oils and their constituents in coping with multidrug-resistant bacteria. Expert Review of Anti-infective Therapy, 10(7), 775-90. https://doi.org/10.1586/eri.12.57 
Lv, F., Liang, H., Yuan, and Q., Li, C. (2011). In vitro antimicrobial effects and mechanism of action of selected plant essential oil combinations against four food-related microorganisms. Food Research International, 44(9), 3057-3064. https://doi.org/10.1016/j.foodres.2011.07.030

Mabuza, M. (2018). Efficacy of Calendula Officinalis as an Antibacterial Agent for In Vitro Pseudomonas aeruginosa. Eurasian Journal of Medicine and Oncology, 2(2), 55-60. https://doi.org/10.14744/ejmo.2017.18189

Mcfarland, J. (1987). Standardizasyon bacteria culture for the disc diffusion assay, Journal of the American Medical Association, 49: 1176-1178.

Meerts, I.A.T.M., Verspeek-Rip, C.M., Buskens, C.A.F., Keizer, H.G., Bassaganya-Riera, J., Jouni, Z.E., van Huygevoort, A.H., van Otterdijk, F.M., and van de Waart, E.j. (2009). Toxicological evaluation of pomegranate seed oil. Food and Chemical Toxicology, 47(6), 1085-92. https://doi.org/10.1016/j.fct.2009.01.031

Odds, F.C. (2003). Synergy, antagonism, and what the chequerboard puts between them. Journal of Antimicrobial Chemotherapy, 52(1), 1.

https://doi.org/10.1093/jac/dkg301

Ozgul-Yucel, S. (2005). Determination of conjugated linolenic acid content of selected oil seeds grown in Turkey. Journal of the American Oil Chemists Society, 82(12), 893-897. https://doi.org/10.1007/s11746-005-1161-7

PaI, M., Murlikrishna, K., Prashant, G., Shivakumar, K., and Chandu, G.N. (2010). Antifungal efficacy of Punica granatum, Acacia nilotica, Cuminum cyminum and Foeniculum vulgare on Candida albicans: An in vitro study. Indian Journal of Dental Research, 21(3), 334-6.

Pandey, A., and Chandel, E. (2014). In vitro evaluation of antibacterial activity of Calendula officinalis against MDR pathogens. World Journal of Pharmacy and Pharmaceutical Sciences, 3(11), 879-98.

Pardo, J.E., Cuesta, M.A., Alvarruiz, A., Granell, J.D., and Álvarez-Ortí, M. (2011). Evaluation of potential and real qualities of virgin olive oil from the designation of origin (DO) "Aceite Montes de Alcaraz" (Albacete, Spain). Food Chemistry, 124(4), 1684-1690

https://doi.org/10.1016/j.foodchem.2010.07.068

Pereira, A.P., Ferreira. I.C.F.R., Marcelino, F., Valentão, P., Andrade, P.B., Seabra, R., Estevinho, L., Bento, A, and Pereira, J.A. (2007). Phenolic compounds and antimicrobial activity of olive (Olea europaea L. Cv. Cobrançosa) leaves. $\quad$ Molecules, $12(5), \quad$ 1153-62. https://doi.org/10.3390/12051153

Russell, A.D. (1991). Mechanisms of bacterial resistance to non-antibiotics: food additives and food and pharmaceutical preservatives. Journal of Applied Bacteriology, 71(3), 191-201. $\quad$ https://doi.org/10.1111/j.1365 2672.1991.tb04447.x

Singh, B., Katiyar, D., Tilak, R., and Srivastava, R.K. (2015). In vitro assesment of antimicrobial potency and synergistic effects of three medicinal plants (Mentha arvensis, Carissa carandas, Calendula officinalis) extract against pathogenic bacteria. African Journal of Microbiology Research, 9(5), 286-293. https://doi.org/10.5897/ajmr2014.7057

Stergiopoulou, T., Meletiadis, J., Sein, T., Papaioannidou, P., Tsiouris, I., Roilides, E., and Walsh, T.J. (2008). Isobolographic analysis of pharmacodynamic interactions between antifungal agents and ciprofloxacin against Candida albicans and Aspergillus fumigatus. Antimicrobial Agents and Chemotherapy, 52(6), 2196-204. https://doi.org/10.1128/aac.00735-07

Subashini, R., and Rakshitha, S.U. (2012). Phytochemical Screening, Antimicrobial Activity and In Vitro Antioxidant Investigation of Methanolic Extract of Seeds from Helianthus annuus L. Chemical Science Review and Letters, 1(1), 30-34.

Sudjana, A.N., D’Orazio, C., Ryan, V., Rasool, N., Ng, J., Islam, N., Riley, T.V., and Hammer, K.A. (2009). Antimicrobial activity of commercial Olea europaed (olive) leaf extract. International Journal of Antimicrobial Agents, 33(5), 461-3. https://doi.org/10.1016/j.ijantimicag.2008.10.026

Trichopoulou, A., Costacou, T., Bamia, C., and Trichopoulos, D. (2003). Adherence to a Mediterranean Diet and Survival in a Greek Population. New $\begin{array}{lll}\text { England Journal of Medicine, 348(26), 2599-608 } & \end{array}$ https://doi.org/10.1056/nejmoa025039

Tuck, K.L., and Hayball, P.J. (2002). Major phenolic compounds in olive oil: Metabolism and health effects. Journal of Nutritional Biochemistry, 13(11), 636644. https://doi.org/10.1016/s0955-2863(02)00229-2

Wang, L.M., Lv, J.P., Chu, Z.Q., Cu1, Y.Y., and Ren, X.H. (2007). Production of conjugated linoleic acid by Propionibacterium freudenreichii. Food Chemistry, 103(2), 313-318. https://doi.org/10.1016/j.foodchem.2006.07.065

Yilmaz, B., and Usta, C. (2010). Therapeutic use of pomegranate (Punica granatum). Türk Aile Hekimliği Dergisi, 14(3), 146-153.

https://doi.org/10.2399/tahd.10.146 